\title{
KARAKTERISTIK KOMUNITAS LAMUN DI PERAIRAN SELAT LONTHOIR KEPULAUAN BANDA
}

\author{
Munira*, Johny Dobo** \\ * Staf Pengajar Politeknik Perikanan Negeri Tual, e-mail: laylanaira@yahoo.com \\ **Staf Pengajar Sekolah Tinggi Perikanan Hatta-Sjahrir Banda Naira, e-mail: -
}

\begin{abstract}
ABSTRAK
Penelitian ini dilakukan sejak bulan Juli hingga Desember 2009 yang bertujuan untuk mengetahui karakteristik komunitas lamun di Selat Lonthoir, Kepulauan Banda, Maluku. Hasil pengamatan menunjukkan bahwa padang lamun di daerah ini termasuk heterospesifik yang terdiri dari 7 (tujuh) spesies, dengan kerapatan jenis tertinggi adalah Cymodocea rotundata di stasiun I dan II serta Thalassia hemprichii di stasiun III. Frekuensi kehadiran relatif tertinggi di stasiun II dan II adalah $C$. rotundata (56,7\% dan $42,8 \%$ ) sedangkan di stasiun III adalah $T$. hemprichii (39,8\%). Penutupan relatif jenis lamun di stasiun I dan II didominasi oleh $C$. rotundata masing-masing sebesar $58,39 \%$ dan $44,34 \%$ sedangkan di stasiun III T. hemprichii merupakan jenis yang memiliki nilai penutupan relative tertinggi yaitu $44,39 \%$.
\end{abstract}

Kata Kunci: Kepulauan Banda, komunitas, lamun

\section{PENDAHULUAN}

\subsection{Latar Belakang}

Kepulauan Banda adalah gugusan kepulauan oseanik yang terletak kurang lebih pada 04031'S dan 129054'BT di Laut Banda Indonesia Timur, dengan panjang garis pantai $84,81 \mathrm{~km}$ dan diperkirakan memiliki luas padang lamun $3,1 \mathrm{~km}^{2}$. Wilayah lamun pada umumnya terbatas (localized) dengan jarak 150 $\mathrm{m}$ dari pantai dan lebar sampai dengan $500 \mathrm{~m}$ sepanjang pantai (David et al. 2002). Padang lamun banyak menyimpan potensi sumberdaya hayati dan merupakan salah satu ekosistem yang tinggi produktivitasnya di dunia, juga menyediakan keragaman yang tinggi pada habitat dan substrat untuk kebanyakan hewan laut. Secara fisik padang lamun merupakan suatu bentuk tahanan yang mempengaruhi pola aliran arus dengan mereduksi kecepatan arus sehingga perairan di sekitarnya menjadi tenang (Randal 1965 in Azkab 2006).

Pemanfaatan daerah pantai untuk berbagai kepentingan dapat berpengaruh terhadap ekosistem lamun. Hal ini seperti yang dilaporkan oleh Kuriandewa (1998) terhadap keberadaan lamun di Teluk Ambon yang mengalami gangguan disebabkan karena adanya proses alami, penangkapan ikan dengan menggunakan bahan kimia, pencemaran limbah domestik pasar dan pemukiman dari daratan dan juga disebabkan oleh pemanfaatan daerah pantai serta peningkatan aktivitas transportasi laut yang menyebabkan limbah organik/anorganik. Di Queensland Australia dilaporkan bahwa ancaman terhadap padang lamun adalah sedimentasi, pengerukan dan pembangunan di daerah pantai, serta aktivitas perahu dan kapal (Colles et al., 2004).

Potensi padang lamun di perairan Kepulauan Banda cukup besar, namun keberadaannya mulai mengalami perubahan sehubungan dengan adanya penurunan kualitas habitat yang disebabkan oleh aktivitas manusia berupa transportasi laut, reklamasi, limbah domestik (pemukiman penduduk), maupun kegiatan penangkapan yang dapat mempengaruhi kondisi lamun di daerah pantai. Adanya tekanan tersebut diduga dapat memberikan pengaruh terhadap produktivitas sumberdaya dimana dengan menurunnya 


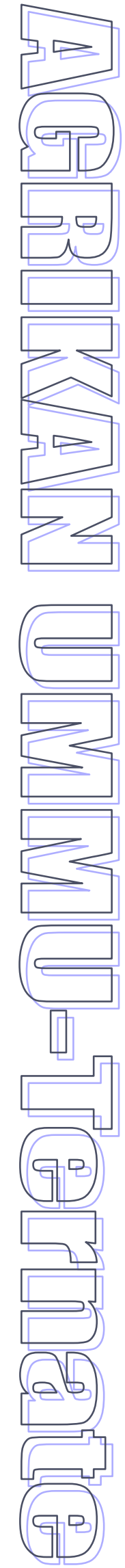

jumlah kerapatan lamun dikhawatirkan akan mempengaruhi keberadaan makanan dan tempat perlindungan bagi biota laut yang hidup di dalamnya. Berdasarkan hal tersebut maka diperlukan suatu pengkajian untuk mengetahui kondisi komunitas lamun yang berada di perairan pantai Selat Lonthoir Kepulauan Banda, Maluku.

\subsection{Tujuan Penelitian}

Tujuan penelitian ini untuk menganalisis karakteristik komunitas lamun meliputi kerapatan, frekuensi kehadiran dan persen penutupan lamun. Manfaat dari penelitian ini adalah diperolehnya informasi tentang kondisi lamun dan diharapkan dapat menjadi salah satu sumber rujukan dalam pengelolaan sumberdaya.

\section{BAHAN DAN METODE}

\subsection{Waktu dan Lokasi}

Penelitian ini dilaksanakan selama enam bulan yaitu bulan Juli hingga Desember 2009 di padang lamun Selat Lonthoir, Kepulauan Banda, Maluku. Metode penelitian yang digunakan adalah deskriptif analitis. Lokasi penelitian dibagi dalam 3 (tiga) stasiun. Stasiun I dan II terletak di Pulau Banda Besar sedangkan stasiun III di Pulau Naira. Stasiun I berada di pantai Lonthoir dengan kondisi substrat dasarnya adalah pasir hingga pecahan karang. Stasiun II berada di pantai Walang dan memiliki substrat dasar pasir berlumpur, sedangkan stasiun III berada di pantai Tita dengan substrat dasar pasir hingga pasir agak berlumpur. Posisi stasiun penelitian selengkapnya ditampilkan dalam Gambar 1.

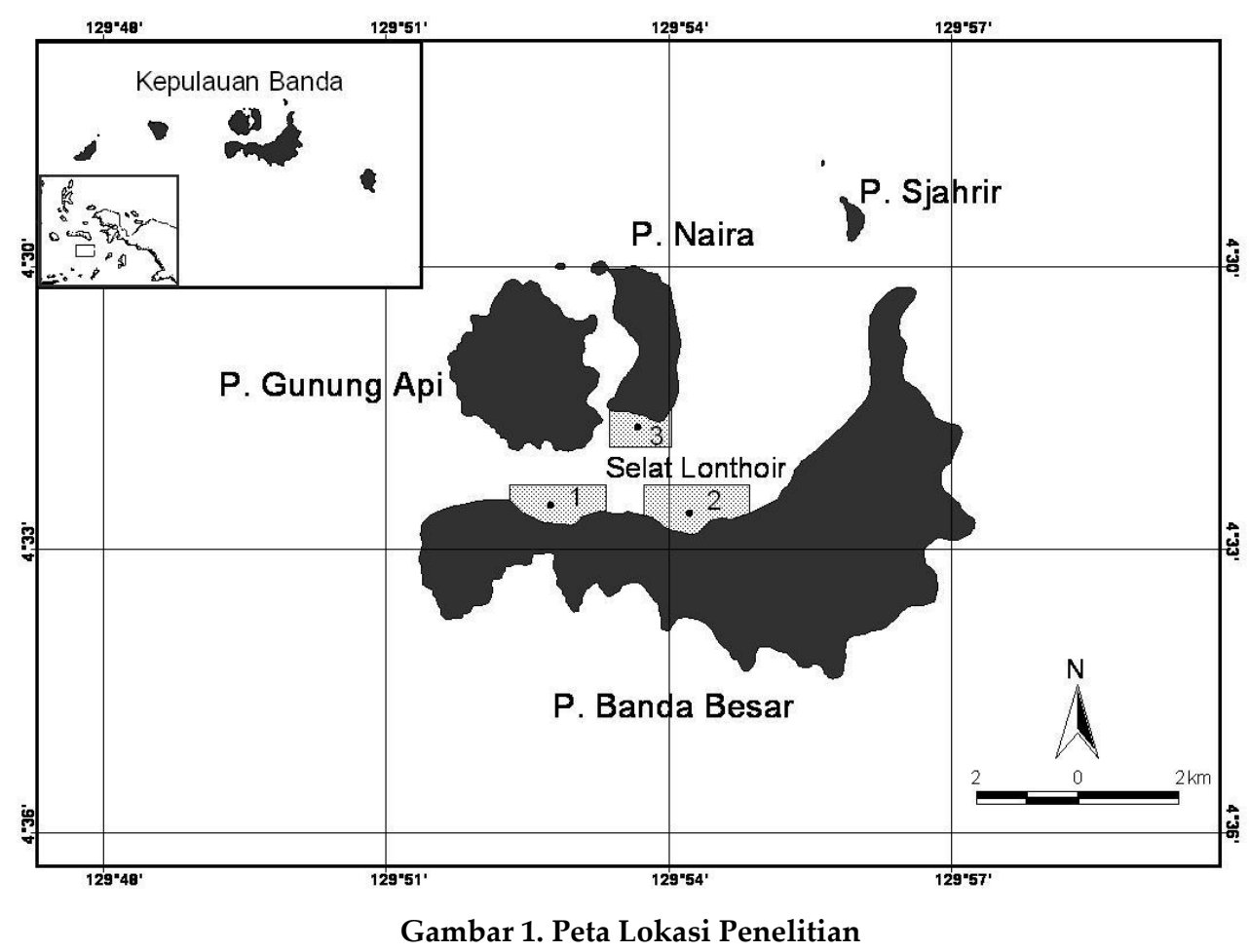

\subsection{Pengambilan Contoh}

Teknik pengambilan menggunakan metode transek garis dan kuadrat berdasarkan petunjuk English et al., (1994). Cara pengambilan adalah ditarik transek garis tegak lurus garis pantai sebanyak 6 transek dimana setiap transek berjarak $25 \mathrm{~m}$. Pada setiap transek garis diletakkan petak kuadrat dengan interval antar petak kuadrat $20 \mathrm{~m}$.
Pengamatan komunitas lamun dilakukan dengan petak kuadrat berukuran $1 \mathrm{~m}^{2}$ pada saat air surut. Pada setiap petak kuadrat dihitung tegakan lamun dari setiap jenis kemudian diambil sebagai contoh, selanjutnya dimasukkan ke dalam kantong plastik serta diberi label stasiun pengambilan, nomor transek garis dan nomor kuadrat pengambilan. Di laboratorium, contoh tersebut kemudian dibersihkan dan dipisahkan menurut jenisnya. 


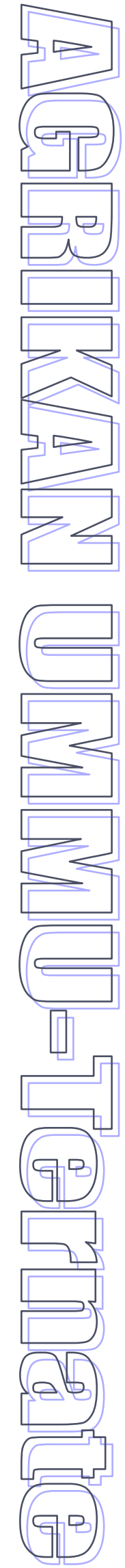

Identifikasi jenis dilakukan menurut den Hartog (1970), Phillips dan Menez (1988) dan Tomascik et al., (1997). Pengamatan untuk melihat penutupan lamun dilakukan dengan petak berukuran $0.5 \mathrm{~m} \times 0.5 \mathrm{~m}$ dan setiap petak kuadrat tersebut dibagi dalam grid-grid berukuran $0.1 \mathrm{~m} \times 0.1 \mathrm{~m}$.

\subsection{Analisis Data}

a. Kerapatan lamun dihitung dengan formula:

$$
K i=\frac{\sum_{i=1}^{n} n i}{A}
$$

keterangan:

$\mathrm{Ki}=$ kerapatan jenis $\mathrm{ke-i}\left(\mathrm{teg} / \mathrm{m}^{2}\right)$

ni $=$ jumlah total individu jenis ke-i (ind)

$A=$ luas area total pengambilan contoh $\left(\mathrm{m}^{2}\right)$

b. Frekuensi jenis lamun dihitung berdasarkan petunjuk English et al.,(1994) sebagai berikut:

$$
F i=\frac{P i}{\sum_{i=1}^{n} P}
$$

Keterangan:

$\mathbf{F i}=$ frekuensi jenis ke-i

$\mathrm{Pi}=$ jumlah petak contoh ditemukannya jenis ke-i

$\Sigma P=$ jumlah total petak contoh yang diamati

c. Perhitungan penutupan jenis lamun dilakukan berdasarkan petunjuk Saito dan Atobe (1970) diacu dalam English et al., (1994):

$$
C i=\frac{\sum_{i=1}^{n}(\text { Mixfi })}{\sum_{i=1}^{n} f i}
$$

Keterangan:

$\mathbf{C i}=$ penutupan $\mathbf{j e n i s} \mathrm{ke-i}$

$\mathrm{Mi}=$ persentase nilai tengah kelas ke-i

$\mathrm{fi}=$ frekuensi (jumlah tutupan kotak-kotak kecil dari jenis ke-i, yang dominan)

$\Sigma \mathrm{fi}=$ jumlah total frekuensi jenis ke-i

\section{HASIL DAN PEMBAHASAN}

3.1. Gambaran Umum Lokasi Penelitian

Selat Lonthoir terletak di perairan Kepulauan Banda, Maluku, berada di antara Pulau Banda Besar, Pulau Neira dan Pulau Gunung Api. Di wilayah ini padang lamun hanya dijumpai di Pulau Banda Besar dan Pulau Neira, sedangkan di Pulau Gunung Api tidak ditemui daerah lamun. Tidak dijumpainya padang lamun di Pulau Gunung Api berkaitan dengan daerah intertidalnya yang sempit dan topografi yang relatif curam sehingga tidak memungkinkan lamun untuk tumbuh dengan baik. Ekosistem yang dominan di pulau ini adalah terumbu karang dan pantai berbatu. Berbeda dengan Pulau Gunung Api, di Pulau Banda Besar dan Pulau Neira bentuk topografi pantai relatif landai. Di kedua pulau ini lamun mulai dijumpai pada jarak 50-70 m dari bibir pantai dengan lebar daerah yang ditumbuhi lamun berkisar antara 100-150 m ke arah laut. Di bagian depan padang lamun langsung dijumpai ekosistem terumbu karang.

Lokasi penelitian dibagi menjadi tiga stasiun yang ditetapkan berdasarkan hasil observasi terhadap keberadaan lamun. Stasiun I berada di pantai Lonthoir yang memiliki daerah intertidal yang cukup luas bila dibandingkan dengan kedua stasiun lainnya. Letak stasiun ini dekat dengan daerah pemukiman penduduk dan dermaga. Daerah pemukiman penduduk dan pantai dibatasi oleh tanggul. Kondisi substrat di lokasi ini terdiri dari pasir berbatu serta pecahan karang. Stasiun II berada di pantai Walang dan berbatasan langsung dengan pemukiman penduduk. Tipe substrat terdiri dari pasir berlumpur dan pasir kasar. Saat melakukan pengambilan data, di stasiun ini sedang berlangsung aktivitas penggalian pasir oleh penduduk sekitar. Stasiun III terletak di pantai Tita berhadapan dengan jalan raya dan tempat wisata. Pada lokasi inipun telah dibangun tanggul yang membatasi daratan dan daerah pantai. Tipe substrat di lokasi ini terdiri dari pasir, pasir berlumpur dan pecahan karang. Pasang surut di wilayah ini adalah tipe campuran yang condong ke harian ganda (mixed tide prevailing semi diurnal), dimana pergerakan air pasang dan surut masingmasing terjadi dua kali sehari dengan tinggi dan periode yang berbeda. Tinggi tunggang air yang terukur mencapai 2,5 m (Dobo 2009).

\subsection{Kerapatan Jenis Lamun}

Hasil pengukuran pada ketiga stasiun penelitian menunjukkan bahwa padang lamun 


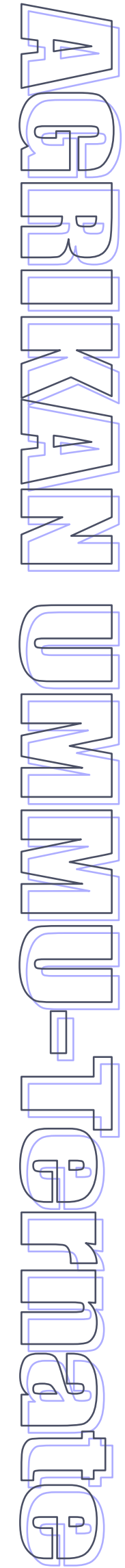

di perairan Selat Lonthoir merupakan vegetasi campuran (heterospesifik) dari tujuh jenis lamun, yaitu Enhalus acoroides, Thalassia hemprichii, Halophila ovalis (famili Hydrocharitaceae), Cymodocea serrulata, Cymodocea rotundata, Halodule uninervis dan Syringodium isoetifolium (famili Potamogetonaceae).

Nienhuis et al., (1989) menyatakan bahwa campuran beberapa spesies lamun dalam suatu lokasi sering didapatkan di padang lamun
Indonesia. Pada beberapa tempat sering dijumpai adanya campuran lebih dari delapan spesies dalam suatu komunitas padang lamun yang saling berasosiasi seperti di perairan Laut Flores, sedangkan di Teluk Kuta dan Teluk Gerupuk, Lombok Selatan dijumpai 11 spesies lamun yang saling berasosiasi (Kiswara dan Winardi 1994). Jenis-jenis lamun yang terdapat pada lokasi penelitian dan perbandingannya dengan perairan lainnya di Indonesia disajikan dalam Tabel 1.

Tabel 1. Perbandingan sebaran jenis lamun di beberapa perairan di Indonesia

\begin{tabular}{lcccccc}
\hline \multicolumn{1}{c}{ Jenis } & \multicolumn{7}{c}{ Lokasi } \\
\cline { 2 - 7 } & $\begin{array}{c}\text { Stasiun } \\
\text { Penelitian }\end{array}$ & $\begin{array}{c}\text { Pulau } \\
\text { Hatta } \\
(2009)\end{array}$ & $\begin{array}{c}\text { Pulau } \\
\text { Kodingareng } \\
(\mathbf{2 0 0 0 )}\end{array}$ & $\begin{array}{c}\text { Lombok } \\
(\mathbf{1 9 9 4 )}\end{array}$ & $\begin{array}{c}\text { Teluk } \\
\text { Banten } \\
(\mathbf{2 0 0 6})\end{array}$ & $\begin{array}{c}\text { Teluk } \\
\text { Banten } \\
(\mathbf{2 0 0 4})\end{array}$ \\
\hline Cymodocea rotundata & + & + & + & + & - & + \\
C. serrulata & + & - & + & + & + & + \\
Enhalus acoroides & + & + & + & + & + & + \\
Halodule pinifolia & - & - & + & + & - & - \\
H. uninervis & + & + & - & + & - & + \\
Halophila decipiens & - & - & - & - & - & - \\
H. ovalis & + & + & + & + & - & + \\
H. ovata-H. minor & - & - & + & + & - & + \\
H. spinulosa & - & - & - & + & - & - \\
Syringodium isoetifolium & + & + & + & + & + & + \\
Thalassia hemprichii & + & + & + & + & + & + \\
Thalassodendron ciliatum & - & + & - & + & - & - \\
\hline Jumlah jenis & 7 & 7 & 8 & 11 & 4 & 8 \\
\hline Keterangan: (+) ada (-) tidak ada & & & & & & +
\end{tabular}

Hasil analisis kerapatan jenis lamun yang diperoleh selama penelitian seperti yang disajikan pada Tabel 2 dan Gambar 2 memperlihatkan bahwa pada stasiun I ditemukan tujuh jenis lamun dengan kerapatan tertinggi diwakili oleh Cymodocea rotundata $\left(369,60 \mathrm{teg} / \mathrm{m}^{2}\right)$ dan yang terendah Syringodium isoetifolium $\left(0,16 \mathrm{teg} / \mathrm{m}^{2}\right)$ sedangkan pada stasiun II dan III ditemukan enam jenis lamun. Nilai kerapatan jenis tertinggi pada stasiun II diwakili oleh Cymodocea rotundata (200,24 teg/ $\mathrm{m}^{2}$ ) dan yang terendah Halodule uninervis $\left(6,29 \mathrm{teg} / \mathrm{m}^{2}\right)$, sedangkan pada stasiun III kerapatan jenis tertinggi adalah Thalassia hemprichii $\left(152,75 \mathrm{teg} / \mathrm{m}^{2}\right)$ dan yang terendah Halodule uninervis $\left(1,83 \mathrm{teg} / \mathrm{m}^{2}\right)$.

Tabel 2. Hasil perhitungan kerapatan jenis lamun di setiap stasiun

\begin{tabular}{lrrrrrr}
\hline \multicolumn{1}{c}{ Jenis Lamun } & \multicolumn{1}{c}{ St I } & \multicolumn{1}{c}{ St II } & \multicolumn{1}{c}{ St III } & Rerata & \multicolumn{1}{c}{ SD } & SE \\
\hline Enhalus acoroides & 2,24 & 46,18 & 56,00 & 34,81 & 28,63 & 16,53 \\
Thalassia hemprichii & 46,64 & 45,24 & 152,75 & 81,54 & 61,67 & 35,61 \\
Cymodocea serulatta & 108,56 & 0,00 & 0,00 & 36,19 & 76,76 & 54,28 \\
Cymodocea rotundata & 369,60 & 200,24 & 136,67 & 235,50 & 164,71 & 116,47 \\
Halodule uninervis & 14,32 & 6,29 & 1,83 & 7,48 & 6,33 & 3,65 \\
Syringodium isoetifolium & 0,16 & 69,59 & 31,50 & 33,75 & 34,77 & 20,07 \\
Halophila ovalis & 48,80 & 13,82 & 27,92 & 30,18 & 17,60 & 10,16 \\
\hline
\end{tabular}


Kerapatan rata-rata jenis lamun di ketiga stasiun berkisar antara 7,48 hingga 235,50 teg/ $\mathbf{m}^{2}$, dengan kerapatan tertinggi adalah Cymodocea rotundata $\left(235,50 \pm 116,47 \mathrm{teg} / \mathrm{m}^{2}\right)$, Thalassia hemprichii $\left(81,54 \pm 35,61 \mathrm{teg} / \mathrm{m}^{2}\right)$, Cymodocea serrulata $\left(36,19 \pm 54,28 \quad \mathrm{teg} / \mathrm{m}^{2}\right)$, Enhalus acoroides $\left(34,81 \pm 16,53 \quad \mathrm{teg} / \mathrm{m}^{2}\right)$, Syringodium isoetifolium $\left(33,75 \pm 20,07 \mathrm{teg} / \mathrm{m}^{2}\right)$, Halophila ovalis $\left(30,18 \pm 10,16 \mathrm{teg} / \mathrm{m}^{2}\right)$ dan yang terendah Halodule uninervis $\left(7,48 \pm 3,65 \mathrm{teg} / \mathrm{m}^{2}\right)$.
Kisaran kerapatan jenis lamun di lokasi ini lebih rendah dari padang lamun di Pulau Hatta 3,85-296,89 teg/ $\mathrm{m}^{2}$ (Dobo 2009), Teluk Kuta, Lombok Selatan (Kiswara \& Winardi 1994) yang berkisar antara 90-2520 teg/ $\mathrm{m}^{2}$, maupun di Teluk Awur, Jepara yang berkisar antara 46,41$545,43 \mathrm{teg} / \mathrm{m}^{2}$ (Merryanto 2000) dan lebih tinggi dari Teluk Banten (Erina 2000) yang berkisar antara $16,7-159 \mathrm{teg} / \mathrm{m}^{2}$.

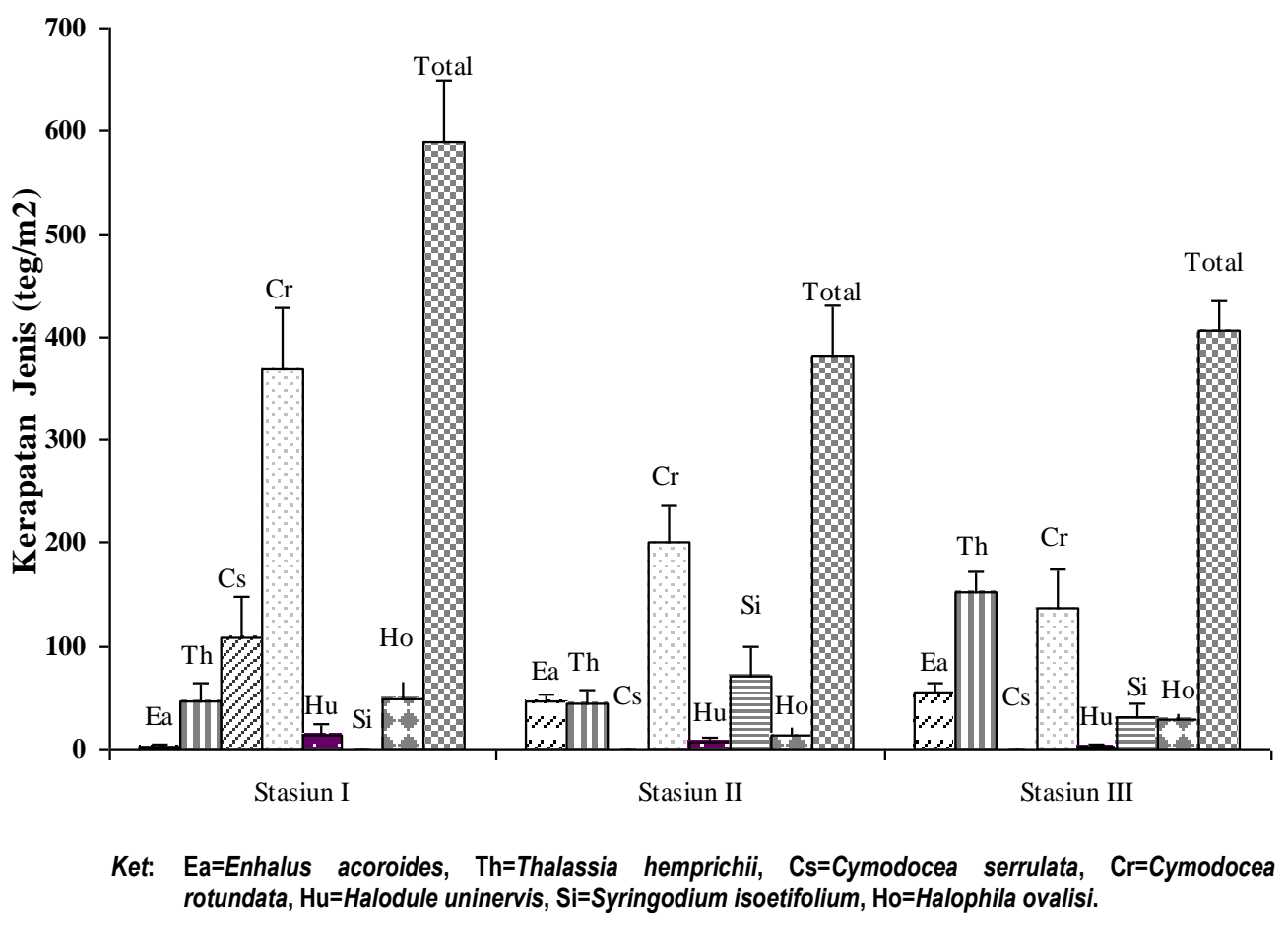

Gambar 2. Kerapatan jenis lamun di Selat Lonthoir

Berdasarkan kerapatan jenis di atas, ada dua jenis lamun yang memiliki nilai yang menonjol dibandingkan dengan yang lain yaitu Cymodocea rotundata dan Thalassia hemprichii. Hal ini memperlihatkan bahwa jenis lamun tersebut mampu beradaptasi pada berbagai substrat. Tomascik et al.,(1997) menyatakan bahwa $C$. rotundata hidup pada daerah dangkal yang tertutup pasir karang dan mempunyai toleransi yang tinggi pada daerah terbuka atau tidak terendam air. Den Hartog (1970) dan Kiswara (2004) melaporkan bahwa T. Hemprichii mampu hidup pada semua jenis substrat, bervariasi dari lumpur, pasir dan campuran pasir dengan pecahan karang.

\subsection{Frekuensi Kehadiran Jenis Lamun}

Frekuensi kehadiran jenis merupakan peluang ditemukannya jenis-jenis lamun dalam plot-plot contoh yang menggambarkan sebaran jenis lamun yang ada. Substrat dasar membatasi sebaran lamun pada suatu area, karena masing-masing jenis memiliki kesukaan terhadap substrat yang berbeda.

Berdasarkan Tabel 3 dan Gambar 3, terlihat bahwa frekuensi kehadiran relatif tertinggi pada stasiun I adalah Cymodocea rotundata $(56,7 \%)$ dan yang terendah Syringodium isoetifolium (0,1\%). Pada stasiun II, frekuensi kehadiran tertinggi diwakili oleh Cymodocea rotundata $(42,9 \%)$ dan yang terendah Halodule uninervis $(\mathbf{1}, 5 \%)$ sedangkan di stasiun III, yang tertinggi adalah Thalassia 


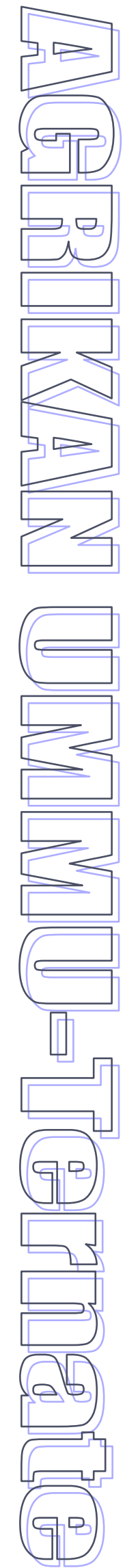

hemprichii $(39,8 \%)$ dan yang terendah diwakili oleh Halodule uninervis $(0,6 \%)$. Tingginya frekuensi kehadiran Cymodocea rotundata pada stasiun I dan II diduga berkaitan dengan kondisi substrat berupa pasir hingga pasir agak berlumpur. Sedangkan ditemukannya Thalassia hemprichii yang sangat dominan di stasiun III, diduga berkaitan dengan tipe substratnya yaitu pasir dengan pecahan karang yang sangat mendukung untuk pertumbuhan jenis tersebut. Kondisi substrat yang berpasir menunjukkan bahwa proses flushing atau pencucian pantai berlangsung baik sehingga proses sedimentasi berlangsung lambat yang menyebabkan kondisi pantai bersubstart pasir ini miskin akan zat hara. Kondisi substrat seperti ini sangat cocok untuk kehidupan jenis lamun Thalassia hemprichii, karena jenis ini cenderung menjadi dominan pada substart keras (den Hartog 1970). Hal ini didukung oleh bentuk morfologi daun yang panjang sekitar 5$20 \mathrm{~cm}$. Dengan ukuran daun seperti ini apabila terjadi hempasan ombak maka tidak akan menyebabkan kerusakan seperti patahnya daun.

Tabel 3. Hasil perhitungan frekuensi kehadiran jenis lamun di setiap stasiun

\begin{tabular}{lcccccc}
\hline \multirow{2}{*}{ Jenis Lamun } & \multicolumn{2}{c}{ Stasiun I } & \multicolumn{2}{c}{ Stasiun II } & \multicolumn{2}{c}{ Stasiun III } \\
\cline { 2 - 7 } & Rerata & SD & Rerata & SD & Rerata & SD \\
\hline Enhalus acoroides & 0,014 & 0,048 & 0,283 & 0,232 & 0,358 & 0,177 \\
Thalassia hemprichii & 0,179 & 0,284 & 0,244 & 0,284 & 0,584 & 0,311 \\
Cymodocea serrulata & 0,193 & 0,352 & 0,000 & 0,000 & 0,000 & 0,000 \\
Cymodocea rotundata & 0,666 & 0,378 & 0,535 & 0,328 & 0,344 & 0,315 \\
Halodule uninervis & 0,020 & 0,072 & 0,019 & 0,068 & 0,008 & 0,037 \\
Syringodium isoetifolium & 0,001 & 0,004 & 0,126 & 0,287 & 0,117 & 0,215 \\
Halophila ovalis & 0,102 & 0,202 & 0,039 & 0,123 & 0,057 & 0,066 \\
\hline
\end{tabular}

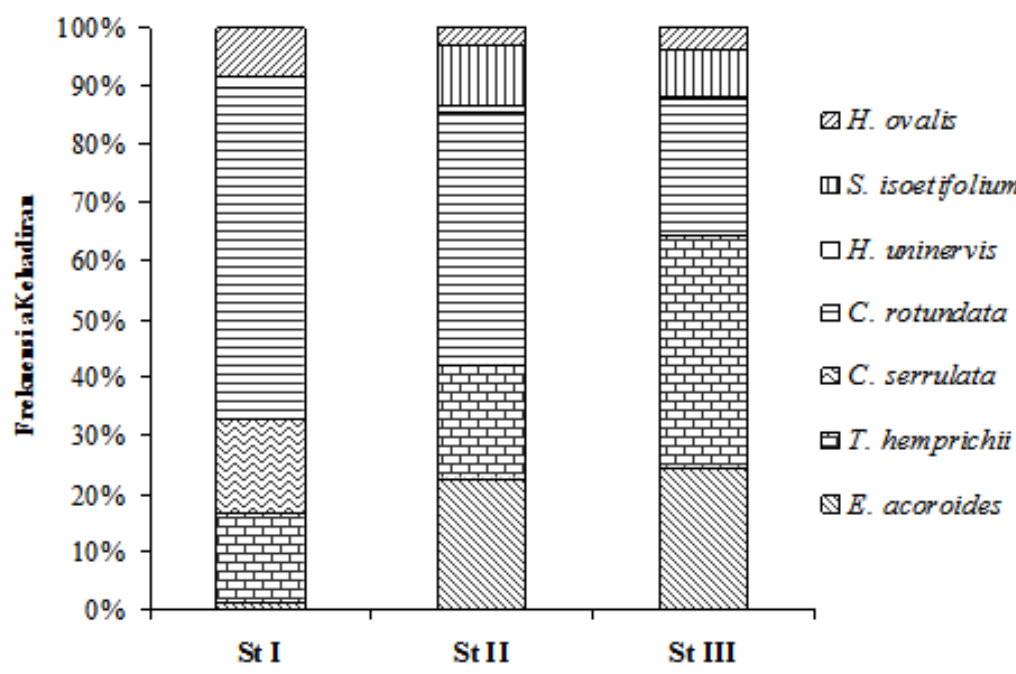

Gambar 3. Frekuensi kehadiran jenis lamun di Selat Lonthoir

Cymodocea rotundata, Halophila ovalis, Syringodium isoetifolium, Halodule uninervis, Thalassia hemprichii dan Enhalus acoroides ditemukan di semua stasiun pengamatan. Hal ini berarti jenis-jenis tersebut mampu beradaptasi untuk hidup pada berbagai substrat dan tersebar cukup merata. Nybakken (1997) menyatakan bahwa jenis lamun Enhalus acoroides mempunyai kecepatan pertumbuhan yang lebih tinggi dibandingkan dengan jenis lainnya. Sehingga diduga kehadiran Enhalus acoroides ada kaitannya dengan kemampuan tumbuh jenis lamun ini. Selain itu keberhasilan E. acoroides ini dipengaruhi oleh sifatnya yang eurycious yaitu mempunyai kemampuan hidup di lokasi manapun. Tomascik et al. (1997) 
